NMAI CONTRIBUTIONS FROM THE

$v, 7$, no. 2 MUSEUM OF THE AMERICAN INDIAN

HEYE FOUNDATION

Vol. VII, No. 2

HENDRICKS-HODGE EXPEDITION

\title{
MEDICAL OBSERVATIONS ON THE ZUNII INDIANS
}

BY

HENRY CRAIG FLEMING, M.D.

MUSEUM OF THE AMERICAN INDIAN

HEYE FOUNDATION

1924 


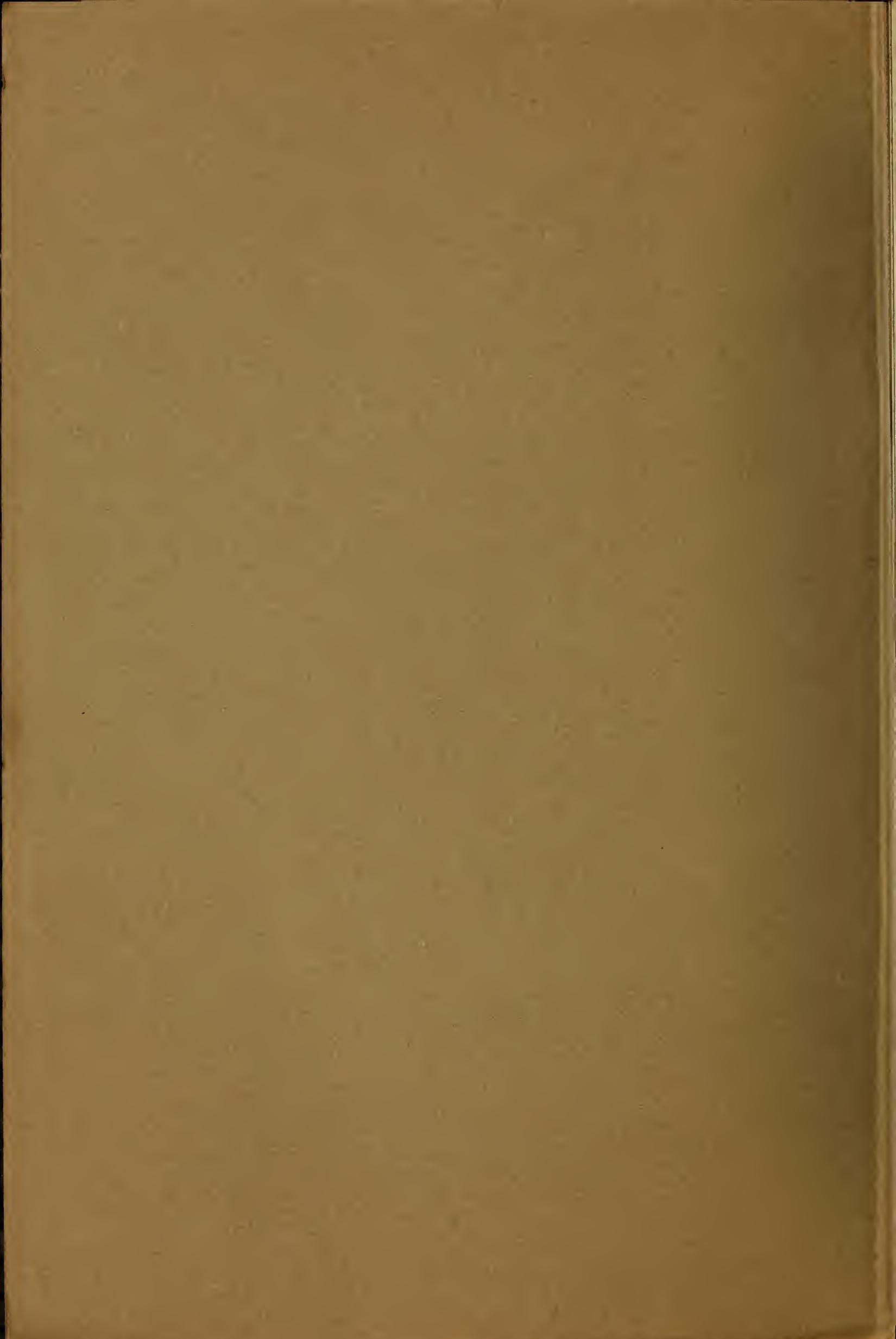




\author{
CONTRIBUTIONS FROM THE \\ MUSEUM OF THE AMERICAN INDIAN \\ HEYE FOUNDATION \\ Vol. VII, No. 2 \\ HENDRICKS-HODGE EXPEDITION
}

\title{
MEDICAL OBSERVATIONS ON THE ZUNII INDIANS
}

\author{
BY \\ HENRY CRAIG FLEMING, M.D.
}





\section{MEDICAL OBSERVATIONS ON THE ZUÑI INDIANS}

\section{RÉSUMÉ OF MEDICAL OBSERVATIONS MADE DURING THE HENDRICKS-HODGE EXPEDITION TO HAWIKUH, NEW MEXICO \\ BY}

HENRY CRAIG FLEMING, M.D.

New York City

$\mathrm{P}^{\mathrm{v}}$

URSUANT to the desire of the Director and of one of the trustees of the Museum of the American Indian, Heye Foundation, that medical observations be made upon the Zuñi Indians, the writer was enabled to conduct the investigation the results of which are incorporated in this brief paper. The study was made during the archeological researches by the Hendricks-Hodge expedition of the Museum at the ruins of Hawikuh in August, 1921.

The Zuñi reservation is situated in western central New Mexico, in its southwestern portion meeting the eastern boundary of Arizona, and comprising an area of 288,040 acres. The average altitude of the valley is approximately 6,500 feet above sea-level. Most of the surface consists of flat, rolling, and rugged country covered generally with sagebrush, cacti, and lesser growths, together with some juniper and piñon trees, but in the loftier districts pines and deciduous trees abound. An occasional oasis, spring, or shallow stream, together with a capacious reservoir fed by the waters of the Zuñi river, make a limited agriculture possible. Frequent rains occur during a portion of the day in the summer season, but the moisture is so soon dissipated by the dry sand and soil, and the hot sun, that both man and beast encounter obstacles to their existence during a large part of the year.

According to an official statement by the Commissioner of Indians Affairs in 1921, the population of the reservation was 1,863 , of which there were 1,063 adlults, 800 minors; 1,040 males and 823 females. 
The Zuñi Indians are distinctly pueblo dwellers, living in stone and adobe houses, terraced one above another, of which most contain two or three communicating rooms, with a small window or two situated high above the earthen floor, usually kept tightly closed and thus affording little or no ventilation. Entrance is by way of a rather narrow doorway, while ascent. to the roofs, to which the Indians frequently resort, as well as to the upper houses, is possible by external ladders. In later years it has been the tendency of the inhabitants to abandon their houses in the main pueblo group, especially when situated in the upper terraces, and to build new dwellings of a single story in the surrounding plain.

The principal pueblo or village of the reservation is Zuñi, or Shíwinakwin, situated on the Zuñi river at an altitude of 6,282 feet. Three less important ones are Nutria, Pescado, and Ojo Caliente, which are occupied chiefly during the farming season and are in close proximity to large springs which irrigate the surrounding fields. Ten or twelve years ago a family settled west of the road from Zuñi to Ojo Caliente, followed by others, so that a new hamlet, known as Ték'yapoawa ("hilly ranch"), has become established. At Zuñi itself are situated a day-school, the postoffice, and the trading post or general merchandise store, and there reside the reservation physician, a missionary, and several white settlers connected with the school and with the trading post. ${ }^{1}$

The school superintendent, who administers all Federal business relative to the inhabitants, lives at Blackrock, about four miles east of Zuni, and here also are situated the Government boarding school and the irrigation reservoir above referred to.

As most of the Zuñis are ignorant of even the simplest laws of hygiene, it is obvious that sanitary conditions are most primitive. Human excrement is frequently deposited in the open, close to the houses in which swarms of flies "blow" the jerked mutton which is commonly hung upon strings or poles to dry for winter use.

\footnotetext{
1 Since this was written the Franciscans have re-established a mission after a lapse of more than a century.
} 


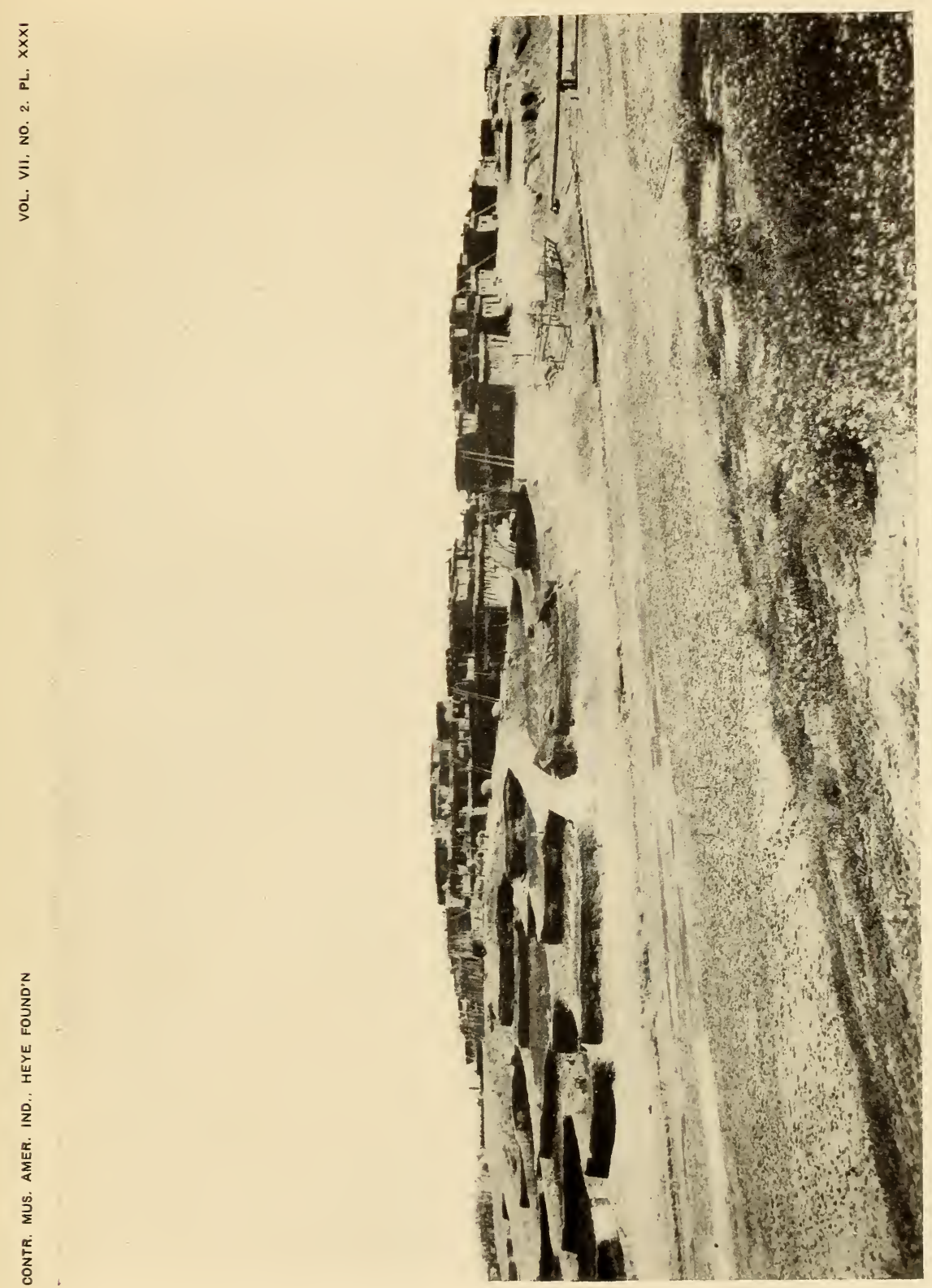

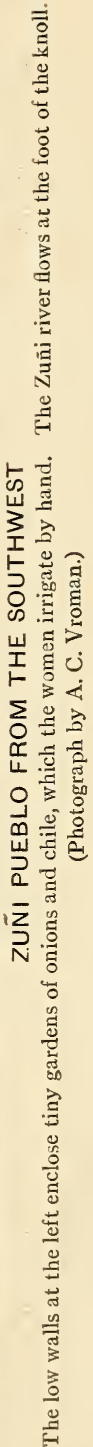




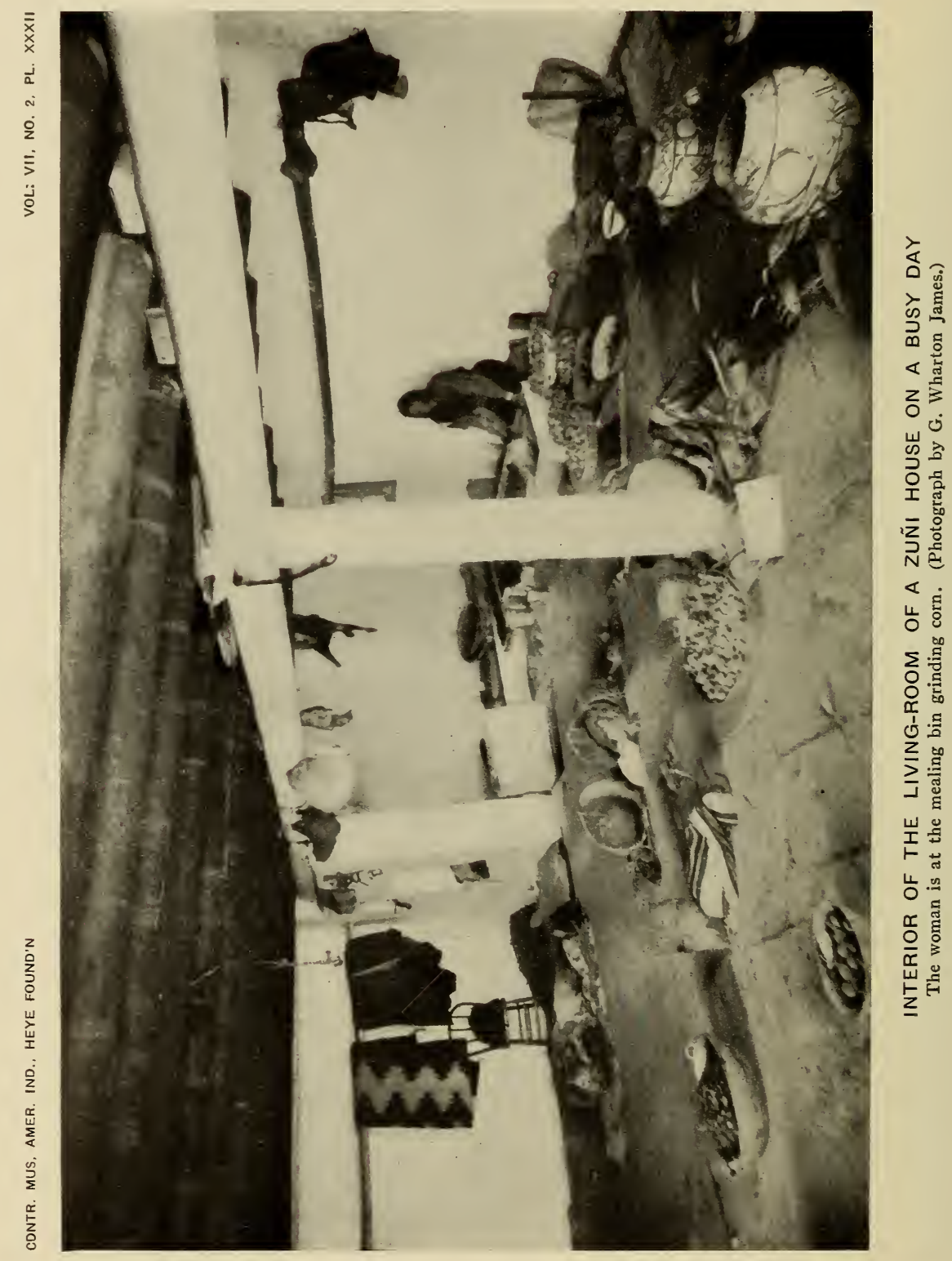


Many lives are sacrificed annually through the ignorant practice of the medicine-men and medicine-women. And it is unfortunately true that very little medical intelligence and efficiency are evident.

The plan of study for making these observations was that of procuring Indians at random, of both sexes and of various ages, for general physical examination, including Wassermann analyses and blood smears and counts, inspection of the pueblo and of general living conditions and customs, and such history taking, by the aid of an interpreter, as might lend constructive support.

At the beginning the writer was advised that difficulty would be encountered in procuring subjects for study owing to the Indians' shyness, religious beliefs, and even resentment of the proposed study. Such, however, did not develop to be the case, for not only did we not experience a single exception to our wishes, but on the contrary many Indians, entirely unsolicited, presented themselves for such studies as we desired to make.

From the standpoint of stature and skeletal development nothing unusual was observed. The Zuñi men range in height from five feet six to five feet ten, with perhaps the majority between five seven and five nine. Most of the women are from two to five inches shorter. The muscles are not large, but are extremely resilient and often very powerful, thus affording great agility and marvelous endurance. The bodies of the younger men are unusually well framed but slender, with readily visible ribs and relatively prominent joints. The feet and legs are well developed, although the muscles are not nearly so large as one would expect to find in a people who run so much as the Zuñis do. There is a striking contrast between them and the jinrickisha men of Japan and China.

It is a common sight to see one or more of these Indians, while going from one pueblo to another, a distance of fifteen or more miles, run the entire distance without stopping to rest. And a favorite pastime is their tribal $t i^{\prime}-k w a-w e$, or race of the kicked stick. This is engaged in by two competing teams usually of four or more runners each. Two cylindrical sticks are cut, one 
for each team. They are about five inches in length by about half an inch or less in diameter, and are differentiated by distinguishing red-paint marks.²

The race is run upon the open prairie over a prescribed course which usually extends from fifteen to twenty miles. Both teams start at the same line, at a given signal, and run the entire distance without abatement, kicking the sticks as they go, but at no time being permitted to touch them with the hands. Even in the event of its falling into a cactus clump or into a prairie-dog hole, the stick must be recovered and further propelled by the foot only, under penalty of disqualification should it be dislodged in any other way. So imbued is the Zuñi with the idea that the stick helps him, instead of himself being the sole motive power of the stick, that he will frankly state that without the stick he could not possibly cover so great a distance in so short a period. It is therefore a common practice when traveling considerable distances on foot, for the men and boys to kick a stick before them.

When a healthy man is stressed by prolonged or violent exercise, breathlessness, consciousness of the heart-beat, faintness and fatigue followed by aching extremities, exhaustion, stiffness of the muscles, and often precordial or even more widespread pain may occur. The nostrils are often dilated and the accessory muscles of respiration are active, to increase the tidal flow of air. It is to such a group of symptoms that Sir Thomas Lewis has applied the term "physiological syndrome of effort"- a narrative of the subjective and objective symptoms of the human body's reaction to physical exertion.

During the war a large number of presumably normal men, regarded as fatigued by exposure and hard work of military duty, manifested effort syndrome. Examination of eight Zuñis immediately after the finish of a stick race, at which time they were bathed in profuse perspiration, revealed comparatively no evidence

\footnotetext{
${ }^{2}$ In the longer, more serious races, the participants in which represent kiva against kiva, or ceremonial chamber, the sticks are often only the length of the middlefinger and much more slender.
} 


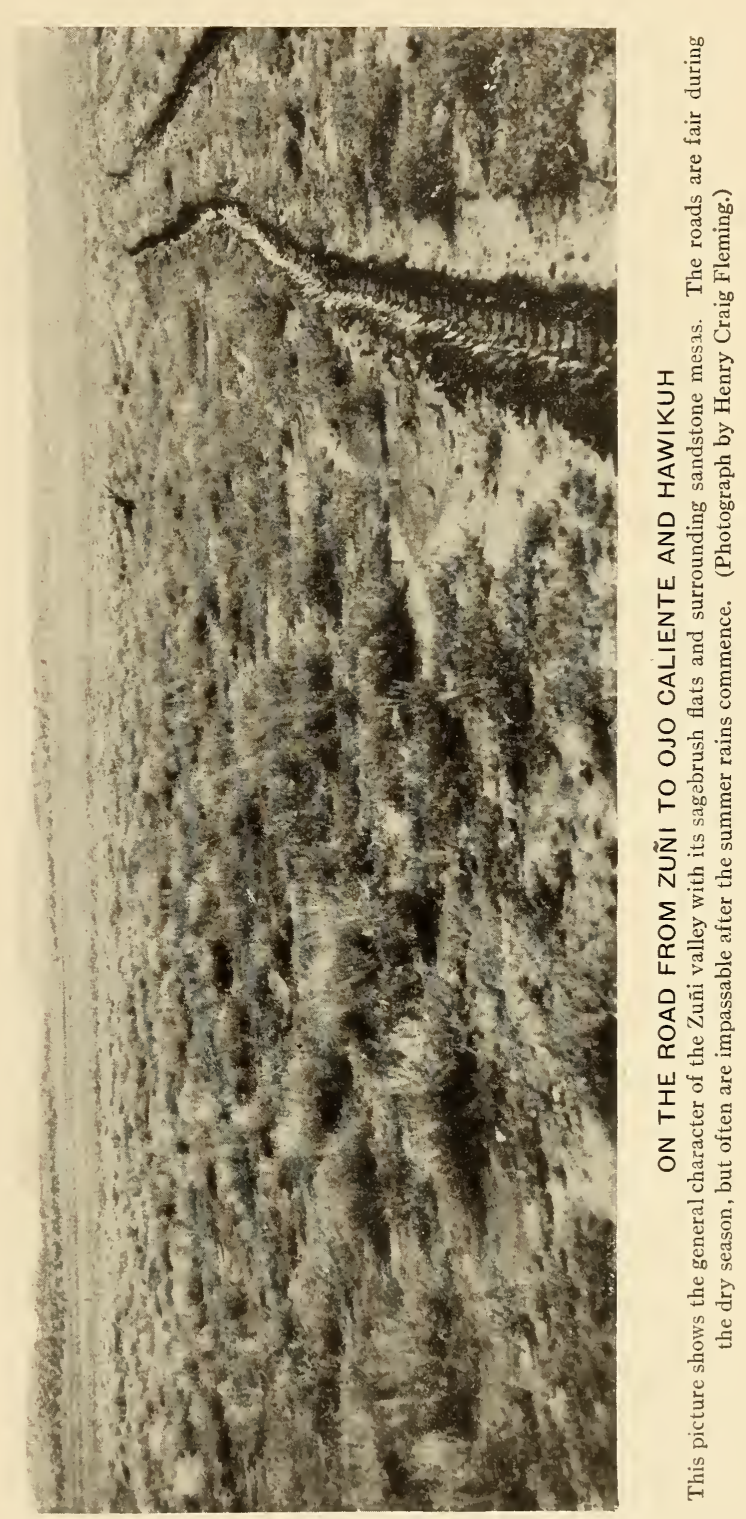




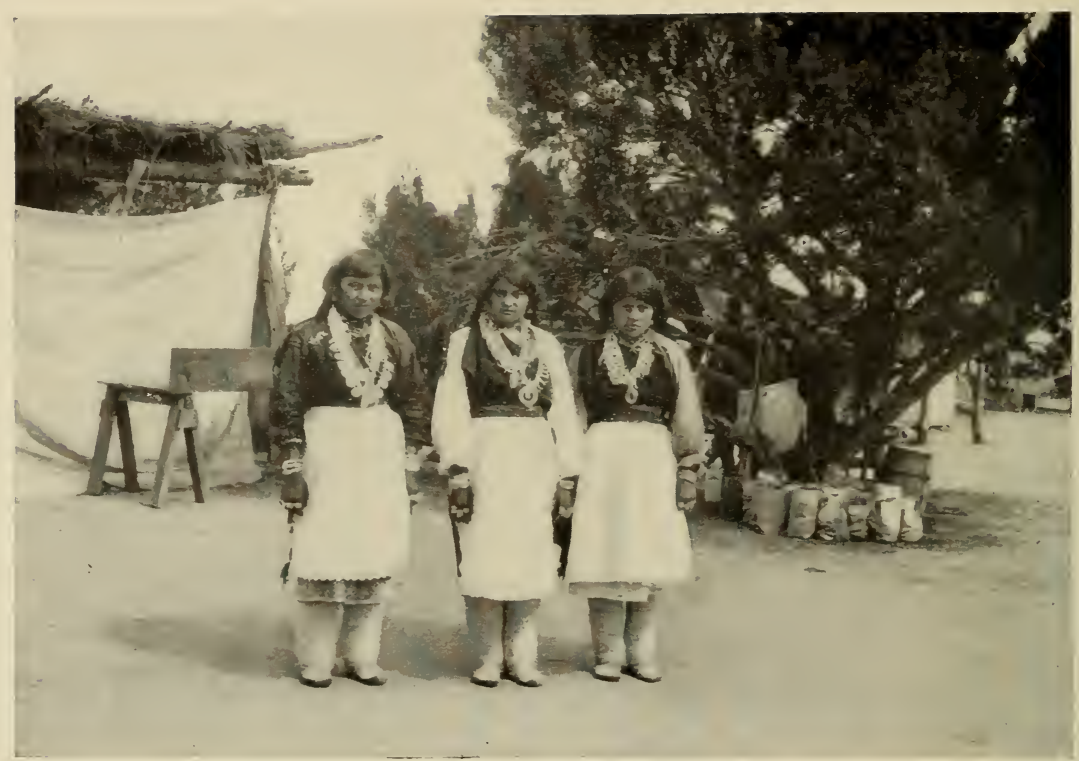

ZUÑ I GIRLS IN NATIVE COSTUME

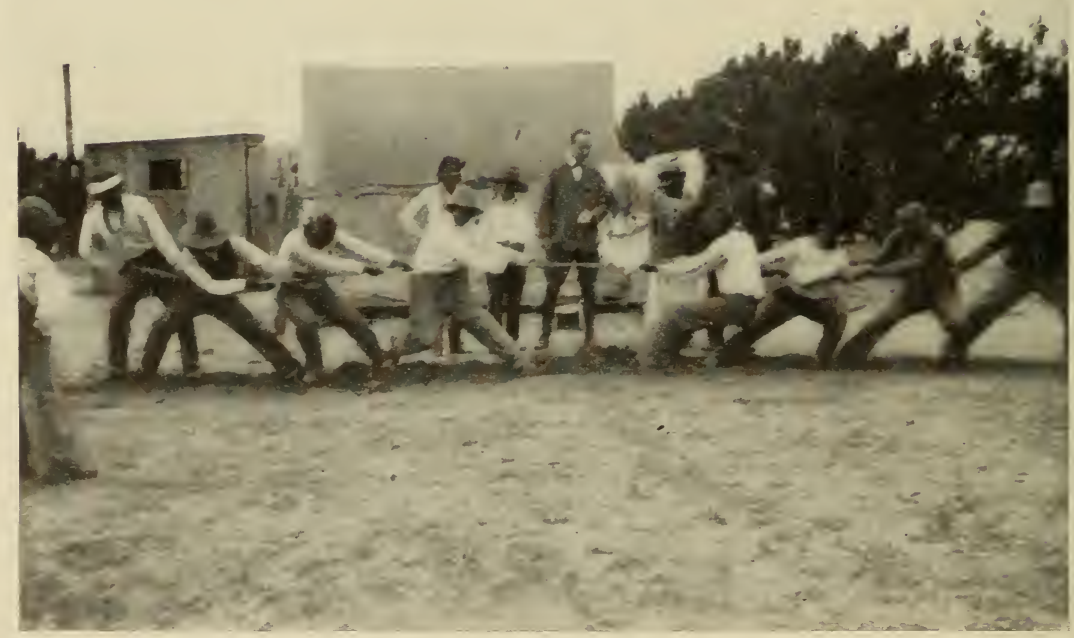

A TUG-OF-WAR

In this contest old and young alike form the competing sides. The old man next to the last at the right is Gaialito, whose portrait is seen in Plate XXXVI. (Photographs by Henry Craig Fleming.) 
of fatigue, no respiratory distress, and no heart rate above 106 beats per minute. The analogy to the soldier during the recent war is, of course, not perfect, for the soldier was plunged into environmental conditions different from his former habit of life, and subjected to the nervous strain of the unusual and unnatural, and hence was put to a more drastic test; but the writer believes the comparison will suffice to illustrate the Indians' great stamina, for in none of those examined was the effort syndrome observed.

Blood pressure by the acoustic method, the diastolic being read at the fifth phase or point at which the pulse sounds disappeared, of approximately one hundred and fifty adults, revealed much lower averages than are found among white people. Of sixty-five cases ranging in age from 50 to 70 years, of which sixteen were women, the systolic pressure ranged from 120 to 130, with diastolic pressure from 58 to 85 . The average range of pressure in seventyfour cases between the ages of 25 and 50 was systolic 110 to 125 , and diastolic 60 to 75 , with no appreciable elevation of either pressure in the older cases of this series. In no instance of the cases examined did a systolic pressure exceed 145 or a diastolic exceed 85, unless there were perfectly definite subjective distress and objective evidence of cardiovascular or renal disturbance.

The writer was surprised to find many men of approximately 70 years of age leading lives of extreme physical activity, performing feats requiring great endurance, and registering systolic blood pressure between 110 and 125 and diastolic pressure between 60 and 75. In one instance, that of Gaialito, an old warrior said to be 75 years of age, the systolic pressure was 110 and the diastolic 80 . This man revealed a definite arcus senilis; as was true of many others, a slight impurity of the first sound at the cardiac apex, and suffered marked impairment of vision, but otherwise was presumably well and not only performed hard manual labor daily, such as digging, but also entered competitive games, such as tug-of-war, with considerable success against younger competitors.

In one instance, a man said to be 55 years of age, apparently in normal health, the systolic blood pressure was 100 , diastolic 
75. In another case, a man of fifty, apparently well, registered systolic 105, diastolic 60. A few cases revealed systolic pressures between 150 and 220, with corresponding elevation of the diastolic pressure, but in each of these cases there was evidence of disease to account for the hypertension.

Altitude unquestionably exerts some influence upon blood pressure, and the study of its effect has been approached in two ways:

(1) $\mathrm{By}$ a study of the pressure of people living at various altitudes.

(2) By the use of the pneumatic chamber to change the atmospheric pressure.

The approximate relation of atmospheric pressure to altitude is illustrated in the following tables from Casmus:

\begin{tabular}{|c|c|c|}
\hline ATMOSPHERTC PRESSTRE & ALTrTtDE & ALtitcde \\
\hline $\mathrm{Im} . \mathrm{Hg}$. & meters & feet \\
\hline 760 & 0 & 0 \\
\hline 660 & 1,148 & 3,760 \\
\hline 560 & 2,370 & 7,760 \\
\hline 460 & 4,022 & 13,200 \\
\hline 360 & 5,945 & 19,470 \\
\hline 260 & 8,600 & 28,180 \\
\hline 200 & 11,000 & 36,040 \\
\hline
\end{tabular}

It has been demonstrated by Schneider and Hedblom ${ }^{3}$ that, in passing from 1,700 to 1,600 feet, falls of relative pressure of from three to seren $\mathrm{mm}$. $\mathrm{Hg}$. occurred without changes in the average diastolic. In ascending from 6,000 to 14,109 feet, they found an average fall of both systolic and diastolic pressures of seven $\mathrm{mm} . \mathrm{Hg}$., and an average rise of pulse rate of 26 beats per minute.

Clough $^{4}$ detected no significant rariation in the average blood pressure of individuals living at an altitude of 5,000 feet and those at sea-level. Studies by Gardner and Hoagland ${ }^{5}$ corroborate

${ }^{3}$ Schneider and Hedblom, American Journal of Physiology, 1908-09.

${ }^{4}$ Clough, Arch. Int. .Med., 1913, xi, 590.

${ }^{5}$ Gardner and Hoagland, Trans. Amer. Climat. Asso., 1905. 


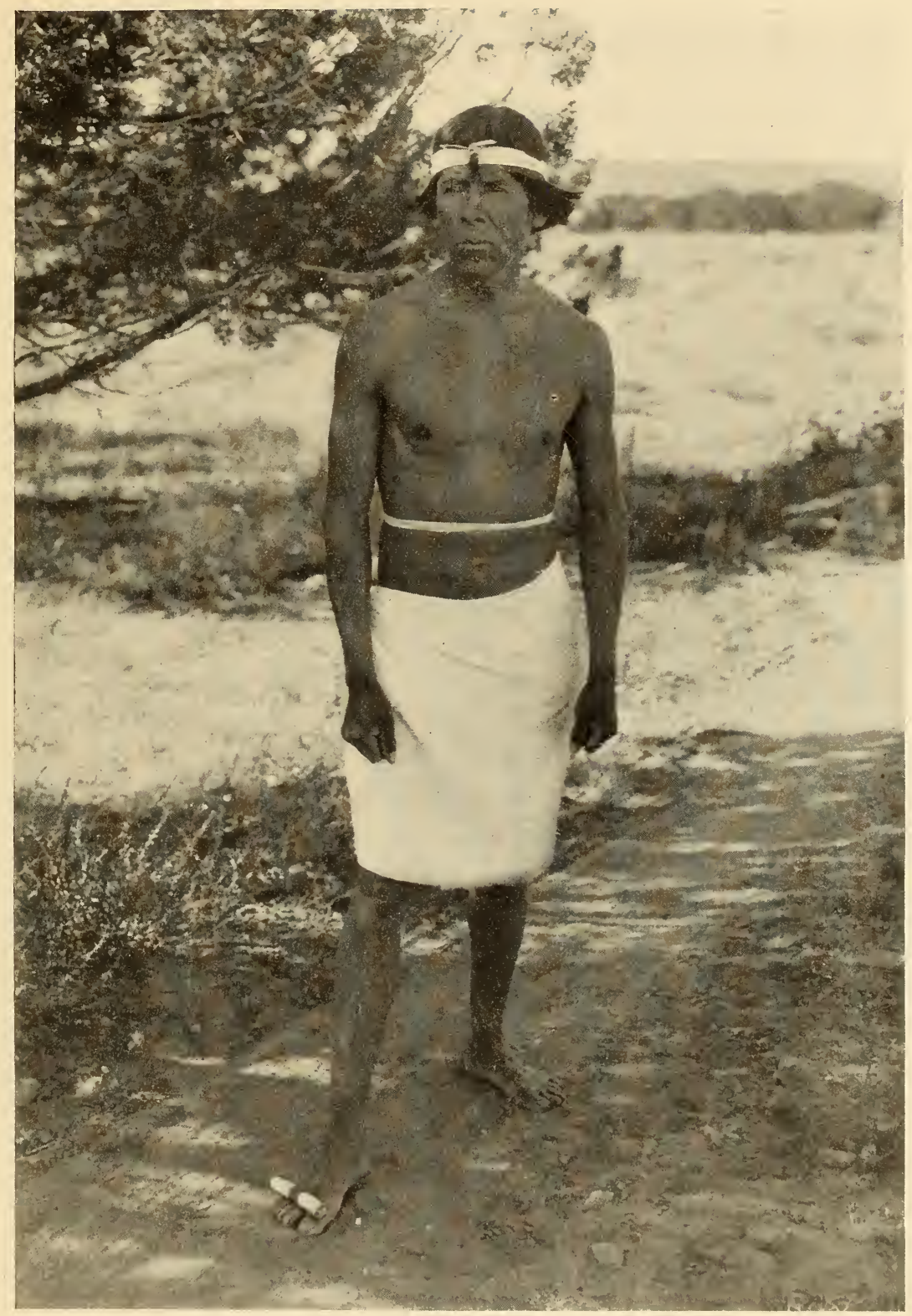

LALIO, THE LEADER OF ONE OF THE TEAMS, WITH HIS STICK ON HIS TOES READY FOR THE KICK-OFF

The Zuñi men range in height from five feet six to five feet ten. The bodies of the younger men are unusually well framed, tut slender. The muscles are not large, but are extremely resilient. (Photographj by E.F. Coffin.) 


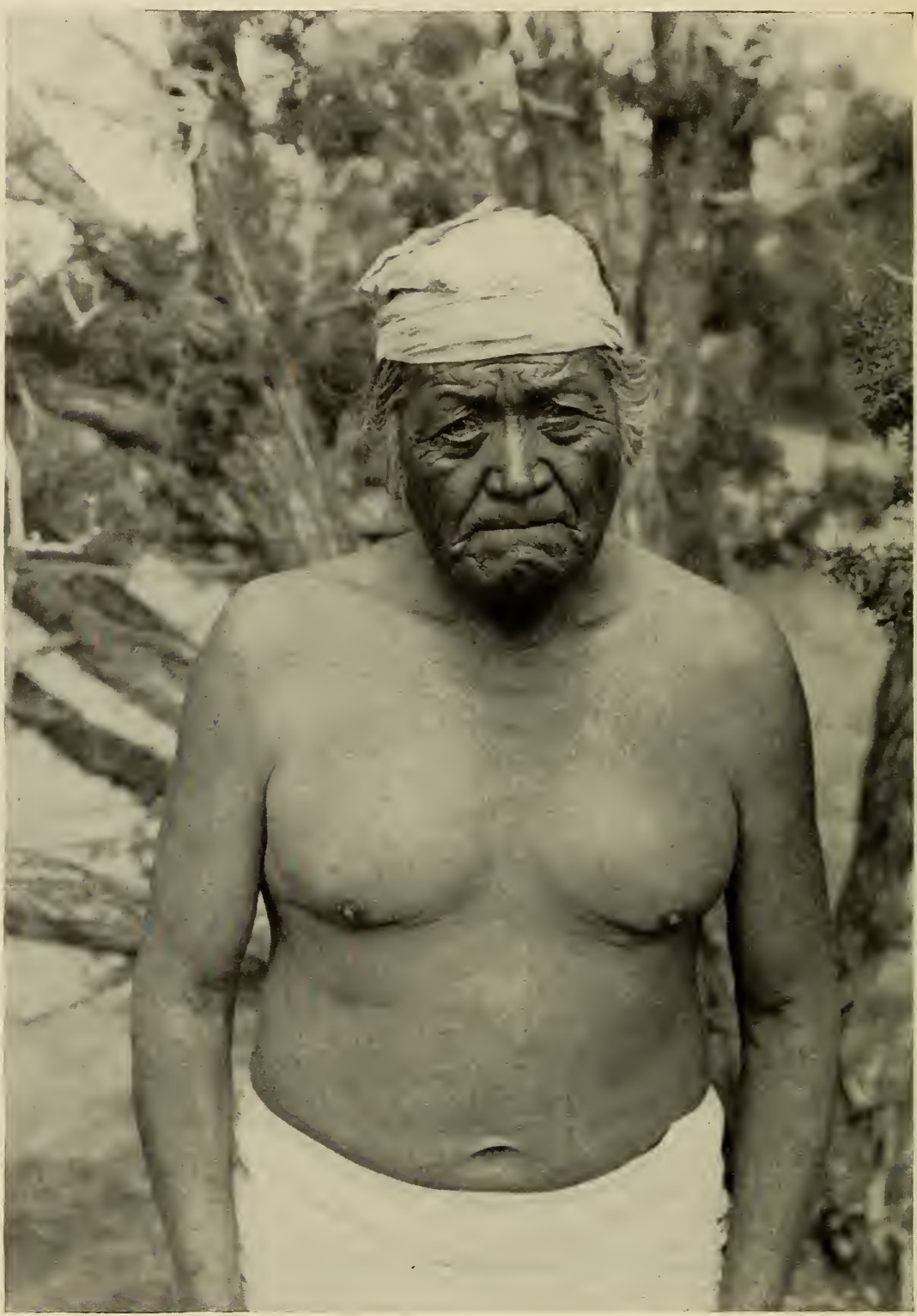

GAIALITO

An old warrior, said to be more than seventy-five years of age, performs hard manual abor daily and has considerable success in competitive games-such as tug-of-war-against younger men. (Photograph by 
in large measure the findings of Clough. They studied individuals living for a year at an altitude of 6,000 feet and found their relative pressures only slightly lower than those observed in persons of the same age and living at sea-level. Smith ${ }^{6}$ believes that an altitude of 6,230 feet does not produce any consistent alteration of blood pressure in either normal or tuberculous individuals.

From numerous studies made, it seems logical to conclude that although ascension tends to lower blood pressure, the degree of lowering is insignificant in the average individual, yet the exception is occasionally witnessed in hypotensive individuals. When appreciable lowering of pressure does occur, it is more pronounced in the systolic pressure.

The writer finds no record of studies of blood pressure having been made upon Indians living at various altitudes or of Indians passing from one altitude to another, but he finds no reason for attributing the remarkably low pressure of the Zuñis to the altitude at which they live.

It is well known that hypotension may occur following hemorrhage, in acute infection, and in chronic conditions of malnutrition or cachexia, in amyloid disease, and in cyclic and orchostatic albuminuria, in anaphylaxis, nicotinism, alcoholism, in endocrine abnormalities, and in other pathological states. Facilities for excluding certain possible contributing factors to the low pressure of the Zunis were not available on the reservation where these studies were made, but the writer believes their hypotension to be constitutional. If this conclusion be correct, it is interesting to note the paradox of the Indians' great powers of endurance and stamina as contrasted with the average white man's deficit of these qualities if he be the subject of low blood pressure.

Inaccuracy regarding the ages of the cases was inevitable because these Indians do not keep a record of the date of birth, and it therefore becomes a matter of conjecture, usually deduced by determining how large a boy or girl the subject was at the time some well-known event occurred in his or her life.

\footnotetext{
${ }^{6}$ Smith, Jour. Amer. Med. Asso., 1915, LXIv.
} 
One hundred and twenty-five differential blood counts were made upon apparently normal men and women of the aforesaid series without detection of abnormality of the white or red cells or of abnormal variation of their numerical relationship.

Seventy-nine specimens of blood for Wassermann analyses were procured from men, women, and children, carefully packed on ice and delivered within forty-eight hours at the laboratory of the Albuquerque Sanitorium. In this series the following results were recorded: Five positive; sixty-seven negative; and seven anticomplementary.

Contrary to the prevailing lay belief that the Indian in general is destined to die of tuberculosis, the writer found at Zuñi evidence of this disease in but seven of about two hundred and fifty cases examined. These examinations, however, consisted of physical methods only, for laboratory and x-ray facilities were not available. In the seven cases presenting definite signs of lung disease, four were third-stage cases and confined by their disease. For the greater part the men, women, and children, although in many instances thin, even emaciated, from lack of proper food, presented well-developed resonant chests with normal respiratory sounds.

Evidence of syphilis too, was very uncommon, as illustrated by lack of physical evidence and negative Wassermann findings.

The one most serious disease prevailing among the Zuñis is conjunctivitis, many of which cases are trachoma. This disease is rampant, almost universally prevalent among them, seriously imperils their vision, and reflects disgrace on the Indian medical service. The writer saw many cases in which large, hard masses had formed upon the conjunctiva by coalescence of the primarily discrete granules, thus creating ulceration, opacity, and in several instances complete destruction of the cornea with resulting blindness. The victims were not only ignorant of the etiology of this destructive and incapacitating disease, but were also devoid of any knowledge for preventing its dissemination. An urgent requisite, therefore, is comprehensive instruction by the reservation physician regarding the individual victim's care of his eyes and methods of destruction of the patho- 


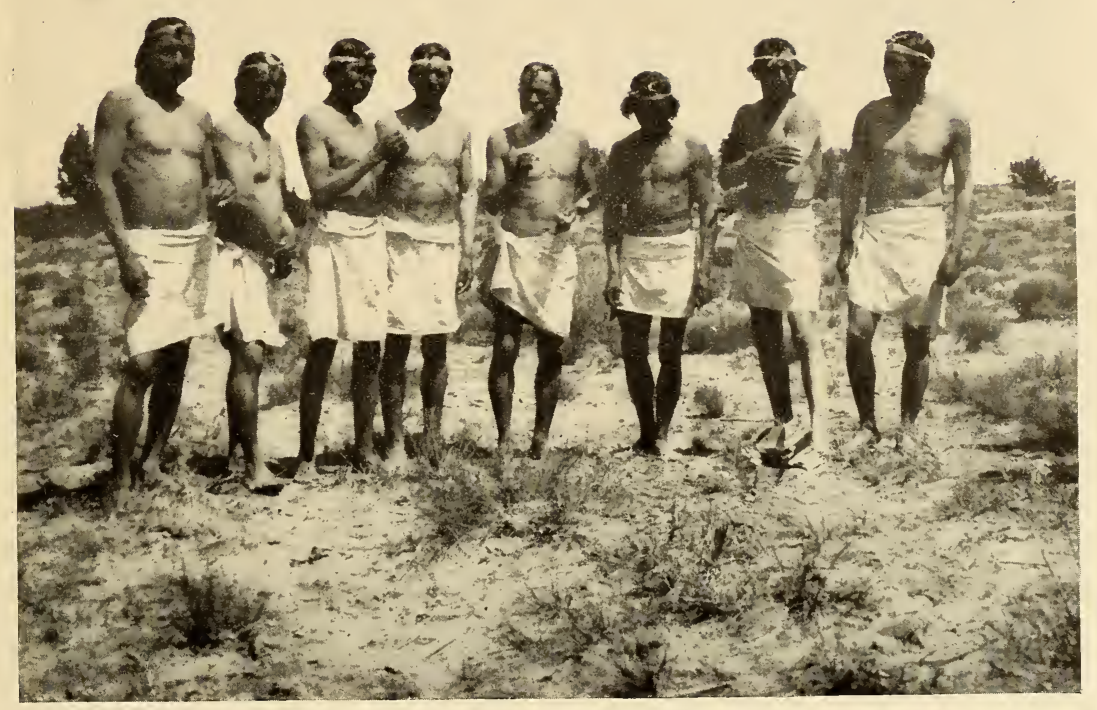

THE TWO TEAMS LINED UP FOR THE STICK-RACE

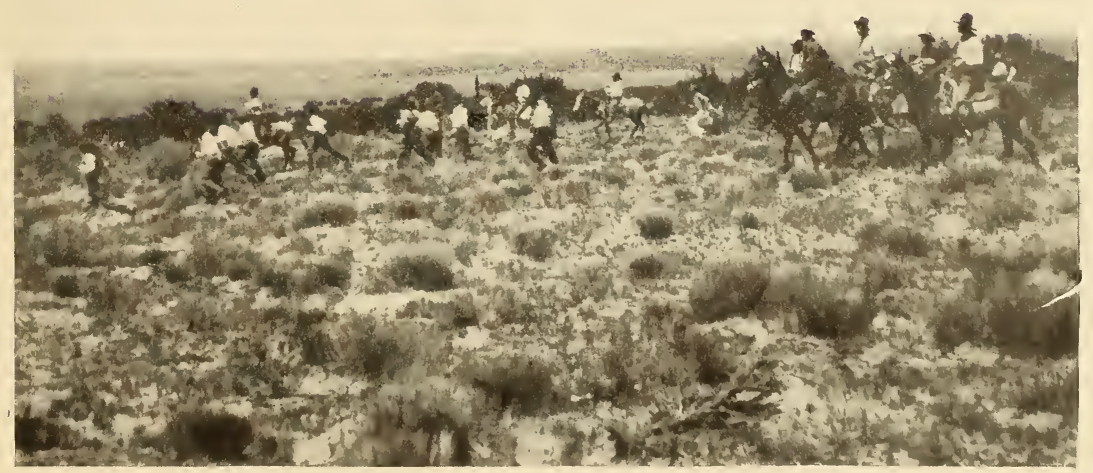

FOLLOWING THE RACERS ON HORSEBACK AND AFOOT

(Photographs by Henry Craig Fleming) 

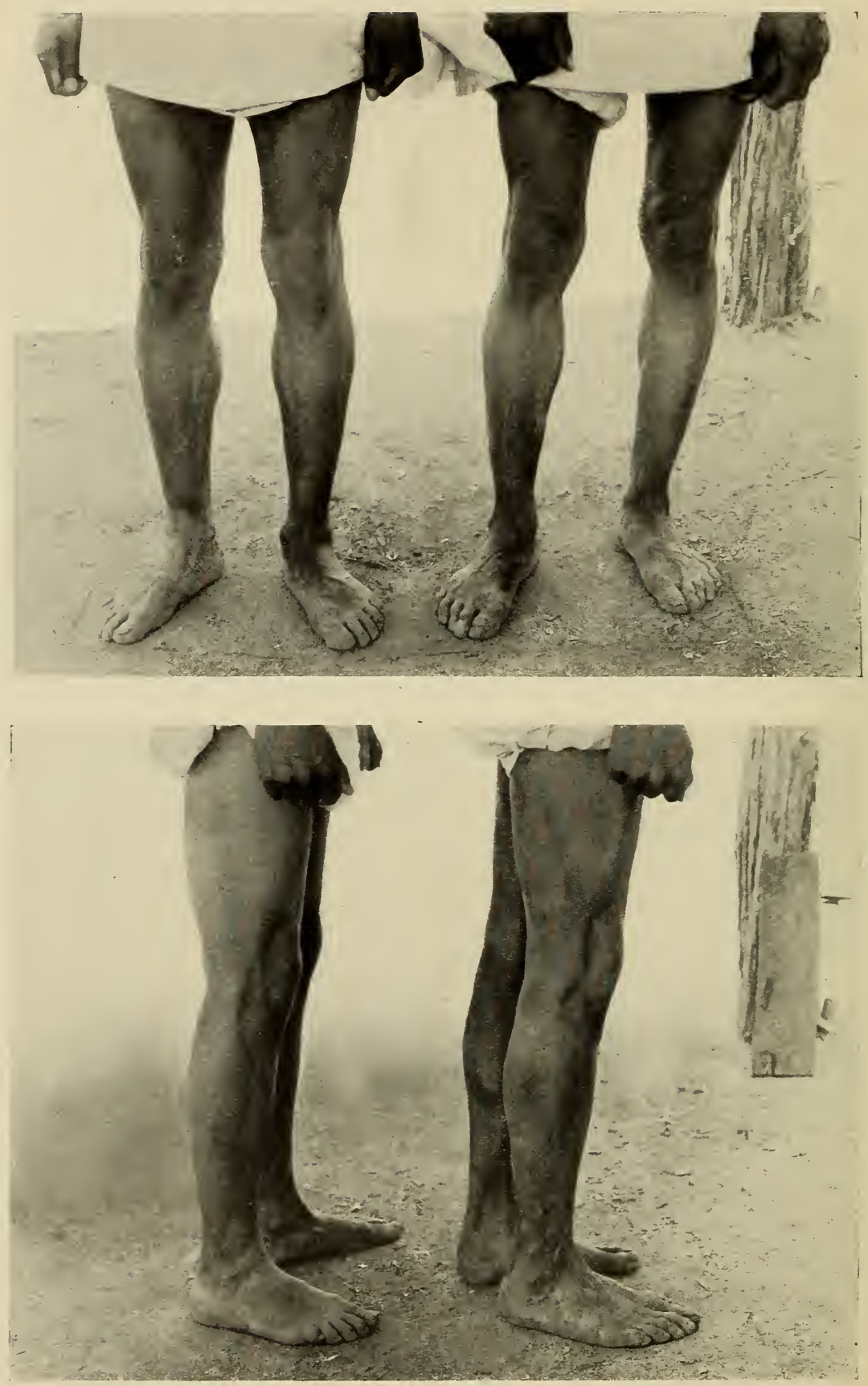

LEGS AND FEET OF ZUÑ i RUNNERS

(Photographs by E. F. Coffin) 
logical secretions. That such instruction would be practicable, would be acceptable, and would probably go far toward preventing this disease, the writer has not the slightest doubt, for in his short residence among these people he found them not only willing but also actually eager to coöperate in any measure which offered benefit. Response to a few applications of a weak solution of silver nitrate was so pronounced in the cases of trachoma which came under the writer's observations that he is firmly convinced that much suffering will be ameliorated and loss of sight from this cause prevented if conscientious, methodical, medical attention could be procured for these Government wards.

In conclusion, the writer feels justified in stating it to be his belief that the prevalence of pestilence and insanitation among the Zuñi Indians in their native environment is due principally to medical negligence and educational neglect.

May a new Congress awaken to the injustice of the Indian situation. May it demand honorable treatment of these wards by the Indian Office, and intelligent attention by medical men who are honest and who have at least average intelligence. Such men can be procured if reasonable renumeration is afforded them. Let the investigation be conducted by those who are qualified by acquaintance with the conditions which prevail and not by political emissaries whose favorable reports of the conscientiousness and efficiency of the Indian administration are foregone conclusions.

The writer wishes to express his deep appreciation of the generosity of Harmon W. Hendricks, Esq., the trustee of the Museum and patron of the Hendricks-Hodge expedition who made possible the studies on which this brief paper is based, and to extend his thanks to Mr. F. W. Hodge, in charge of the field work of the expedition, whose knowledge of the Zuñis and whose congenial relations with them greatly facilitated these observations. 


SMITHSONIAN INSTITUTION LIBRARIES

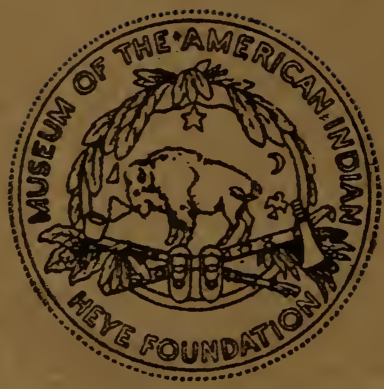

